\title{
The rational locator reexamined: Are travel times still stable?
}

\author{
DAVID LEVINSON* \& YAO WU \\ Department of Civil Engineering, University of Minnesota, 500 Pillsbury Drive SE, Minneapolis, \\ MN 55455, USA \\ (*Author for correspondence, E-mail: levin031@umn.edu)
}

\begin{abstract}
The rational locator hypothesis posits that individuals can, if they choose, maintain approximately steady journey-to-work travel times by adjusting their home and workplace. This hypothesis was coupled with the observation of long-term stability in drive alone journey-to-work times in metropolitan Washington (those times were unchanged from 1957 through 1968 to 1988). Despite the increase of average commuting distance and congestion, trip duration remained constant or even declined when controlling for travel purpose and travel mode because of shifting a share of traffic from slow urban routes to faster suburban routes. This observation has significance, as it is important to know for travel demand analysis if there is an underlying budget, or even a regularity, as this helps us determine whether our forecasts are reasonable. To re-test the underlying rationale for the hypothesis: that travel times are stable, intra-metropolitan comparisons of travel times are made using Washington DC data from 1968, 1988, and 1994, and Twin Cities data from 1990 and 2000. The results depend upon geography. For the larger Washington DC region, keeping the same geography shows little change in commute times, but using the larger 1994 area suggests an increase in commute times. However, the Twin Cities, starting from a much shorter commute time, shows a marked increase over the decade, using either the smaller or the larger geography. Despite the remarkable continuing observation of stability in drive alone commuting times in metropolitan Washington, we reject the theory of personal commuting budgets, as we find that not only are commuting times not generally stable over time at the intra-metropolitan area, but that commuting time clearly depends on metropolitan spatial structure.
\end{abstract}

\section{Introduction}

"Rational Locators," including both individual households and firms, respond to changes in transportation supply by siting themselves to reduce commuting times. $¥$ The key policy implication we see is that over the long term, individual Locators act rationally to balance total costs as measured in dollars and minutes, and total benefits, as measured in proximity, space, and other preferences. These individual calculations result in the polycentric, and dispersing, urban form that exists today throughout the United States. (Levinson \& Kumar 1994)

The rational locator hypothesis thus posits that individuals can, if they choose, maintain approximately steady journey-to-work travel times by adjusting their home and workplace. The hypothesis was inspired by the observation of long-term stability in journey-to-work times in metropolitan 
Washington (those times were unchanged from 1957 through 1968 to 1988). Despite the increase of average commuting distance and congestion, trip duration remained constant or even declined when controlling for travel purpose and travel mode. Levinson and Kumar (1994) argue that this seeming paradox is due to a decreasing share of traffic using slow urban surface streets and a larger share using faster suburban routes. Even with increasing congestion on suburban roads, they remain faster than city streets. This increasing use of suburban routes results from increasing suburbanization of houses, workplaces, and other activities. The hypothesis that individuals and firms mutually locate to maintain travel times provides a mechanism to account for rising travel distances, rising congestion, but constant travel time or commuting time budgets. While the hypothesis was suggested by stable travel times, it also provides a mechanism to explain why commuting times might rise, but less slowly than the increase in commute distance and congestion would suggest.

We can identify three potential types of budgets. The first is the daily time budget of $1440 \mathrm{~min}$. The second is a daily travel time budget, which has been posited by a number of researchers and is discussed in the following paragraph. Third is the possibility of a commuting time budget, discussed in the previous paragraph, which only relates to trips to and from work. Commuting time is, for workers, the dominant share of travel time, so these two notions are related, but not identical. In particular, commuting time can be seen as a more spatial phenomenon, since the area between home and work (and in a small radius around each) defines an individual's territory, and sets the area where other workday activities may conveniently take place. As transportation speeds have risen over the decades and centuries, the space enclosed by a given commuting time has increased. On the other hand, an overall travel time budget is largely a temporal phenomenon, which relates more to time available for travel and for doing other things.

The stability of overall daily travel time has been granted the status of "law" within parts of the transportation community (Hupkes 1982; Kölbl \& Helbing 2003). Travel time budgets have been observed and posited as a basis for analyzing travel demand (e.g. Zahavi 1974; Zahavi \& Ryan 1980; Zahavi \& Talvittie 1980; Rossi 1997; Shafer 2000), been given an anthropological basis (Marchetti 1994), and disputed as being but one factor in a richer economic analysis (Prendergast \& Williams 1981; Tanner 1981). However, Zahavi was not so naïve to think that the budget was rigid: “... time and money budgets are not constant, but they are functions of several variables. For instance, the travel time budget is related to travel speed (level of service) available to travelers and also to car ownership or household income and possibly to urban structure." (Zahavi \& Talvitie 1980). Wee et al. (2002) find evidence against 
such a budget. Mokhtarian and Chen (2003) reviews the literature on overall travel time budgets and finds it mixed.

The related theory of commuting tolerances implies that individuals who find, that over time, their commute has crept beyond their tolerance due to factors like congestion, will readjust their travel and location choices to make their commute tolerable. Unlike a budget however, a tolerance does not imply that commuters will spend a fixed amount of time, rather that the total amount traveling will be under some level. This has been suggested at least since Getis (1969), and has been reconsidered by van Ommeren et al. (1997). Collectively, the empirical results suggest a tolerance zone in the range of a $30-45 \mathrm{~min}$ separation between workplace and home. To achieve a tolerable commute, individuals may relocate their home or workplace. If individuals are concerned about the duration of commute, those who recently moved or changed jobs should have a shorter than average commute. Levinson (1997) examined the relationship between the separation of home and workplace and commute time, and found that those who recently moved had a commute duration that was similar to those who had not recently moved, neither higher nor lower, suggesting people are on average maintaining their commute when relocating. Clark et al. (2003) review the literature on job search and its relationship to the commute, especially long commutes.

Levinson and Kumar (1994) noted that there was a great deal of underutilized capacity, particularly for suburb-to-suburb trips in metropolitan Washington DC. Moreover, simply due to the greater travel speeds on suburban routes, additional demand on those routes, while making them more congested, may increase system average speed as the proportion of travelers using slow urban routes declines. However, the relative lack of road expansion in recent years in the United States, coupled with still growing demand and rising congestion, suggests that some of the excess capacity may have been absorbed. Figure 1 illustrates the discrepancy in the Twin Cities, for example, between traffic growth and road capacity growth.

The 2000 Census (as well as previous data) clearly indicates that average journey-to-work times vary among metropolitan areas in the United States. Perhaps, it is as simple as people in different metropolitan areas having different preferences. On the other hand, perhaps, the differences are attributable to metropolitan land use and transportation characteristics, such as population density and congestion. Urban areas with greater populations generally appear to have worse congestion, but exceptions to this trend do exist.

However, the 2000 Census also shows that journey-to-work times have risen since 1990 for most metropolitan areas, seemingly contradicting the commuting or travel time budget observations (Pisarski 2002). In part, this may be an artifact of metropolitan areas extending more broadly in space, thereby including more exurbanites in the analysis (increasing the sample of those with 


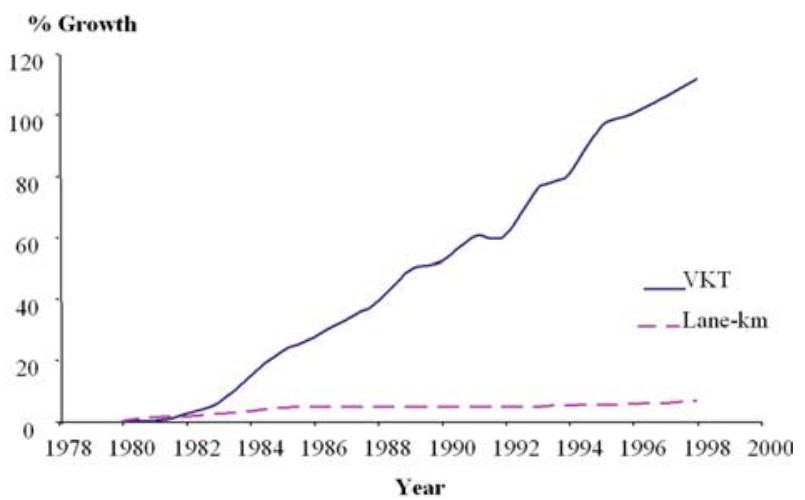

Figure 1. Vehicle-km traveled (VKT) vs. Lane-km growth in the Twin Cities.

a known preference for or tolerance of long commutes). Part may be due to changing preferences for travel time (people increasing their tolerance for long commutes). And part may be due to congestion rising faster than individuals can adapt by relocating (changing homes or jobs requires a significant transaction cost). Congestion within nearly every metropolitan area continues to worsen both in severity and duration (TTI 2001).

This paper conducts two intra-metropolitan analyses to better understand the responses of individuals to changing travel environments: a statistical analysis of the 1968, 1987-1988, and 1994 metropolitan Washington DC Household Travel Surveys, and the 1990 and 2000 Travel Behavior Inventories from the Twin Cities of Minneapolis and Saint Paul, Minnesota. We use these two cities because of the author's familiarity, and because of previous literature analyzing questions about travel time budgets in earlier years using these two cases (e.g. Zahavi \& Ryan 1980; Levinson \& Kumar 1994; Barnes \& Davis 1999). Washington DC is a classic monocentric city which developed a number of suburban activity centers; the Twin Cities is a bit more complex in that it has always been bi-centric, though has also seen the emergence of significant suburban employment over the past three decades. This allows us to study the trend of commuting times and to understand the daily allocation of time among different activities, stratifying individuals by work status, gender, mode used, and metropolitan location.

\section{Data}

We consider within city changes over time. The data used include 1968, 1988, and 1994 household travel surveys in the metropolitan region of Washington DC and 1990 and 2000 home interview surveys of the Twin Cities metropolitan 
area. The data collection methodologies for these two regions are largely the same: a weekday was assigned to each of the randomly selected households and information on the demographic, socioeconomic, and trip making characteristics of the residents was gathered (Metropolitan Washington Council of Governments 1997). The 1968 survey used in-person interviews, 1987-88 was mail-out, mail-back, and 1994 was a computer aided telephone interview (CATI). For the Twin Cities, the 1990 and 2000 surveys were mailed out, and the day after the travel day, interviewers called the participating households to obtain and record the travel information for each household member, and enter it into the computer. Each dataset contains a household file, a person file, and a trip file. The household file records vehicle ownership, household size, and household income; the person file records gender, age, and work status; the trip file includes the locations and purposes of the origin and destination of each trip, transportation mode, vehicle occupancy, departure time, and arrival time (thus giving the travel time directly, and allowing us to compute the activity duration).

The 1988 survey of Washington DC consists of a sample of 8000 households and 55,000 trips; the 1994 data involved 5000 households making over 40,000 trips. The 1990 home interview survey in the Twin Cities area was based on 9700 households and 98,000 trips; the 2000 survey includes 6200 households and 58,000 trips.

For the analysis of the change of the activity patterns, only adults (ages 18$65)$ are considered. Six activities are defined for this study: home, work, workrelated, shop, other, and travel. In order to exclude outliers in the analysis, only travelers who started the day from home and returned home at the end of the day are considered; workers are defined as people who made work trips during the survey day, and all individuals who did not work that day are counted as non-workers.

For the Washington DC data to compare with the results from 1968 and 1988 data, the modes of transportation are divided into auto-1, auto-2, auto-3, and transit. While auto-1 refers to a car with only one person (drive-alone), auto-2 has two people (driver and passenger), and auto-3 has three or more (driver and two or more passengers). In the Twin Cities data, the purposes and modes are treated in a slightly different manner, which will be discussed below.

The jurisdictions of metropolitan Washington DC for which data were collected in 1988 include the District of Columbia; Montgomery and Prince George's counties in Maryland; Arlington, Fairfax, Loudoun, and Prince William counties in Virginia; and the cities of Alexandria, Falls Church and Fairfax in Virginia. In 1994, the area was expanded to include Calvert, Charles, and Frederick counties in Maryland; Fauquier and Stafford counties in Virginia; and Manassas City and Manassas Park City in Virginia. Similarly, the metropolitan Twin Cities data for 2000 were collected on a larger geographic 
area than the 1990 data. In 1990, seven counties were used: Hennepin, Ramsey, Dakota, Anoka, Washington, Scott, and Carver, while in 2000, this number expands to 20 (adding Chisago, Goodhue, Isanti, Le Sueur, McLeod, Mille Lacs, Rice, Sherburne, Sibley, Wright, Pierce, Polk and St. Croix). To examine changes in travel times, the results of the more recent survey are used while both controlling for geographic area and using the larger survey area (no control).

Figure 2 shows the breakdown of the gender and work status for adults (age 18-65) in Washington and Twin Cities surveys. For Washington, the sample size of 1994 is slightly smaller than that of 1988, and the percentage of each category shows little variation. The overall employment rate for women increased from 78 to $82 \%$, while the male labor force participation rate remained at $86 \%$. In the Twin Cities, the overall employment rate for women increased from 73 to $83 \%$, and for men it increased from 90 to $92 \%$.

\section{Activity duration}

Activity duration is the time spent at an activity, which shows how the $1440 \mathrm{~min}$ in a day are allocated to different activities for different groups of people. The duration of each activity is calculated from a travel diary by subtracting the arrival time from the departure time of the next trip. To estimate the duration of the last (or first) activity, assume that the person will make the first trip on the

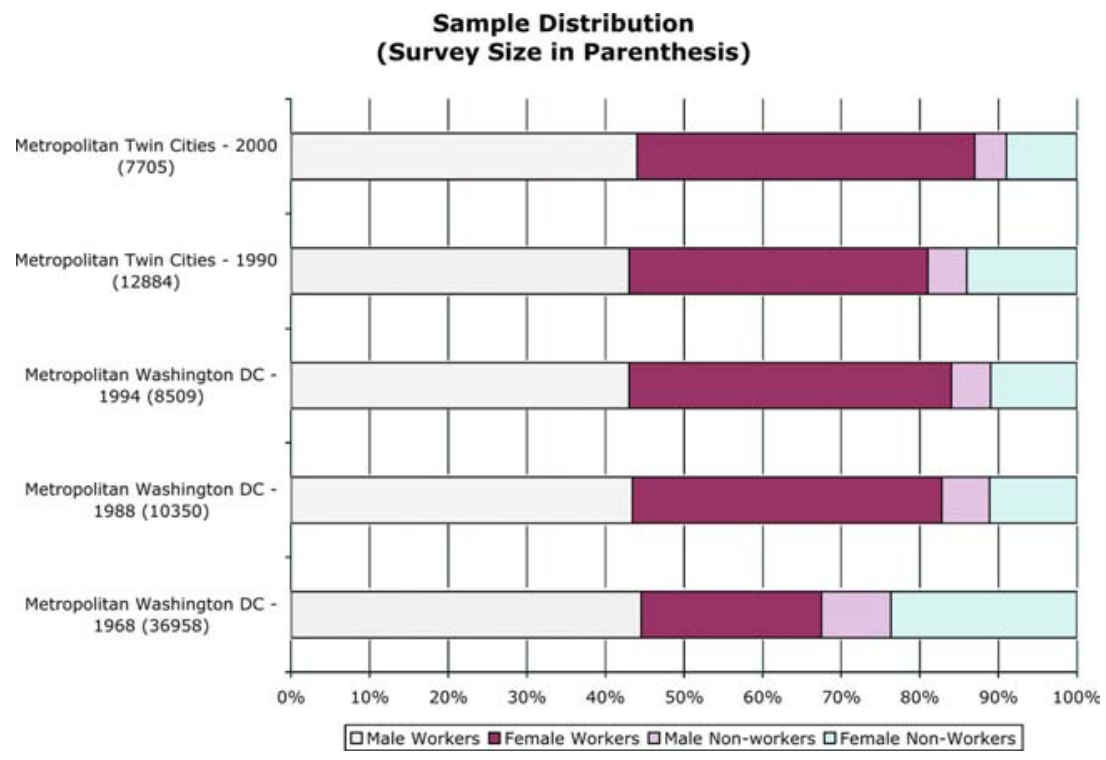

Figure 2. Sample distribution. Note: Excluding work-at-home. 
following day at the same time as that of the previous day. The duration of the last activity is obtained by adding $1440 \mathrm{~min}$ to the departure time of the first trip and then subtracting the arrival time of the last trip.

Mean activity duration for the Washington metropolitan region is summarized in Table 1, for the Twin Cities area in Table 2. In both tables, the parameter is classified by the work and gender status for each activity. An examination of median (rather than mean) values gave the same implications, also activity frequencies were calculated, but these tables are not shown for reasons of space.

Table 1 shows that workers and non-workers, males and females spent less time at home in the Washington area. The reduction for male workers is $38 \mathrm{~min}$ and for female workers it is $31 \mathrm{~min}$. The male working time apparently increased by $27 \mathrm{~min}$ in 1994, for female workers it increased by $29 \mathrm{~min}$. The amount of time

Table 1.

\begin{tabular}{|c|c|c|c|c|c|c|c|c|c|}
\hline \multirow[t]{3}{*}{ Activity } & \multirow{3}{*}{ Year } & \multicolumn{4}{|c|}{ Work outside home } & \multicolumn{4}{|c|}{ Non-workers } \\
\hline & & \multicolumn{2}{|l|}{ Male } & \multicolumn{2}{|c|}{ Female } & \multicolumn{2}{|l|}{ Male } & \multicolumn{2}{|c|}{ Female } \\
\hline & & Mean & S.D. & Mean & S.D. & Mean & S.D. & Mean & S.D \\
\hline \multirow[t]{4}{*}{ Home } & 1968 & 786 & 143 & 831 & 135 & 1120 & 229 & 1225 & 164 \\
\hline & 1988 & 799 & 150 & 826 & 153 & 1143 & 196 & 1165 & 187 \\
\hline & 1994 & 761 & 131 & 795 & 129 & 1093 & 219 & 1155 & 190 \\
\hline & 1994(full) & 760 & 133 & 797 & 132 & 1104 & 219 & 1158 & 194 \\
\hline \multirow[t]{4}{*}{ Work } & 1968 & 515 & 143 & 487 & 116 & 0 & & 0 & \\
\hline & 1988 & 472 & 173 & 447 & 165 & 0 & & 0 & \\
\hline & 1994 & 499 & 145 & 476 & 133 & 0 & & 0 & \\
\hline & 1994(full) & 498 & 149 & 473 & 133 & 0 & & 0 & \\
\hline \multirow[t]{4}{*}{ Work-related } & 1968 & 0 & & 0 & & 0 & & 0 & \\
\hline & 1988 & 0 & & 0 & & 0 & & 0 & \\
\hline & 1994 & 20 & 72 & 10 & 49 & 0 & & 0 & \\
\hline & 1994(full) & 21 & 75 & 10 & 48 & 0 & & 0 & \\
\hline \multirow[t]{4}{*}{ Shop } & 1968 & 7 & 24 & 10 & 32 & 27 & 62 & 52 & 77 \\
\hline & 1988 & 10 & 41 & 13 & 41 & 31 & 62 & 50 & 90 \\
\hline & 1994 & 8 & 28 & 13 & 28 & 33 & 75 & 47 & 77 \\
\hline & 1994(full) & 8 & 27 & 13 & 28 & 34 & 75 & 47 & 76 \\
\hline \multirow[t]{4}{*}{ Other } & 1968 & 44 & 100 & 29 & 76 & 217 & 214 & 101 & 143 \\
\hline & 1988 & 61 & 118 & 62 & 112 & 187 & 187 & 140 & 156 \\
\hline & 1994 & 47 & 78 & 47 & 75 & 220 & 204 & 154 & 165 \\
\hline & 1994(full) & 46 & 77 & 48 & 76 & 207 & 197 & 149 & 163 \\
\hline \multirow[t]{4}{*}{ Travel } & 1968 & 88 & 51 & 82 & 48 & 76 & 58 & 62 & 50 \\
\hline & 1988 & 99 & 63 & 92 & 61 & 80 & 64 & 85 & 73 \\
\hline & 1994 & 104 & 57 & 99 & 56 & 93 & 69 & 85 & 67 \\
\hline & 1994(full) & 108 & 60 & 100 & 57 & 95 & 73 & 86 & 72 \\
\hline
\end{tabular}

Note: Bold Italics indicates 1988 baseline, or cells not statistically different from 1988 using a twotailed $t$-test at $95 \%$ confidence level. Normal font indicates cells are statistically different. 
Table 2. Mean activity duration per day (in min) for 1990 and 2000, Twin Cities metropolitan area, adults $18-65$.

\begin{tabular}{|c|c|c|c|c|c|c|c|c|c|}
\hline \multirow[t]{3}{*}{ Activity } & \multirow[t]{3}{*}{ Year } & \multicolumn{4}{|c|}{ Workers } & \multicolumn{4}{|c|}{ Non-workers } \\
\hline & & \multicolumn{2}{|l|}{ Male } & \multicolumn{2}{|c|}{ Female } & \multicolumn{2}{|l|}{ Male } & \multicolumn{2}{|c|}{ Female } \\
\hline & & Mean & S.D. & Mean & S.D. & Mean & S.D. & Mean & S.D. \\
\hline \multirow[t]{3}{*}{ Home } & 1990 & 777 & 127 & 816 & 137 & 1092 & 227 & 1176 & 182 \\
\hline & 2000 (7county) & 777 & 128 & 802 & 131 & 1044 & 248 & 1122 & 200 \\
\hline & 2000(full) & 775 & 130 & 805 & 132 & 1045 & 248 & 1124 & 202 \\
\hline \multirow[t]{3}{*}{ Work } & 1990 & 485 & 143 & 466 & 129 & 0 & & 0 & \\
\hline & 2000 (7county) & 494 & 133 & 476 & 127 & 0 & & 0 & \\
\hline & 2000(full) & 497 & 136 & 476 & 125 & 0 & & 0 & \\
\hline \multirow[t]{3}{*}{ Work-related } & 1990 & 29 & 81 & 11 & 45 & 83 & 168 & 14 & 68 \\
\hline & 2000 (7county) & 14 & 58 & 9 & 43 & 96 & 188 & 33 & 112 \\
\hline & 2000(full) & 14 & 57 & 9 & 43 & 91 & 185 & 32 & 112 \\
\hline \multirow[t]{3}{*}{ Shop } & 1990 & 7 & 22 & 15 & 32 & 21 & 43 & 41 & 61 \\
\hline & 2000 (7county) & 8 & 20 & 14 & 32 & 26 & 53 & 36 & 57 \\
\hline & 2000(full) & 8 & 20 & 14 & 30 & 25 & 52 & 38 & 64 \\
\hline \multirow[t]{3}{*}{ Other } & 1990 & 53 & 85 & 55 & 79 & 144 & 167 & 131 & 144 \\
\hline & 2000(7county) & 56 & 87 & 56 & 83 & 168 & 189 & 161 & 157 \\
\hline & 2000(full) & 55 & 90 & 54 & 82 & 171 & 191 & 158 & 156 \\
\hline \multirow[t]{3}{*}{ Travel } & 1990 & 88 & 53 & 77 & 43 & 101 & 82 & 78 & 59 \\
\hline & 2000(7county) & 90 & 53 & 84 & 45 & 106 & 95 & 87 & 57 \\
\hline & 2000 (full) & 90 & 55 & 83 & 46 & 107 & 95 & 88 & 60 \\
\hline
\end{tabular}

Note: Bold Italics indicates 1990 baseline, or cells not statistically different from 1990 using a twotailed $t$-test at $95 \%$ confidence level (indicates $t<1.96$ ). Normal font indicates cells are statistically different.

spent at home declined by about the same as the amount of time increased at work. Simply put, workers work more at the expense of lost leisure time.

One should be suspect of such a large change over such a short period. Maybe subtle (or not subtle) changes in the survey methodology affected this result. However, increased time at work is shown from 1990/91-1995 (a similar period) in the Nationwide Personal Transportation Survey (NPTS) as well, for male workers rising from 338 to $365 \mathrm{~min}$, for female workers rising from 284 to 313 min (Levinson \& Kanchi 2002) - a virtually identical change (though from a smaller base). Note that this change occurred just before the widespread adoption of the Internet, which we expect will cause marked differences in time allocation, so some other explanation is warranted. The 1990/91 NPTS was conducted during a recession and the Gulf War, which may have had some impact (lowering time at work, increasing time at home), while the 1995 study was during a boom. However, the Washington DC data (1987/88 and 1994) were both during economic expansions. 
The Twin Cities data show similar patterns but different magnitudes. As shown in Table 2, workers in this area worked more in 2000 than in 1990, but not as much as those in the Washington region. The increase in this decade for both men and women was approximately $10 \mathrm{~min}$. As in Washington, people spent less time at home. For non-workers, the time is reduced by $50 \mathrm{~min}$.

In Washington, the time spent at travel increased for all groups of people, and so did the number of trips. For the same geographic area, the travel time for all people increased from 93 to $98 \mathrm{~min}$, a 5\% increase; while for the whole survey area in 1994, the number is $100 \mathrm{~min}$. In the Twin Cities the time spent at travel rose from $84 \mathrm{~min}$ to $90 \mathrm{~min}$ when controlled for the same geographic area. When the analysis moves to the larger area, the travel time remains the same.

\section{Travel duration}

The interesting finding of a rise in overall travel time needs to be elaborated upon. In order to study the change of travel times, trips are stratified by purpose and mode. For Washington DC data, the seven purposes are: hometo-work, work-to-home, home-to-other, other-to-home, work-to-other, otherto-work, and other-to-other. The travel modes are auto-1, auto-2, auto-3, and transit, which are defined above. The purposes for Twin Cities that are considered are work and other trips (both home-based) and the modes are cars and buses.

As noted earlier, previous studies showed that the auto drive-alone commuting times remained constant between 1968 and 1988 in the Washington metropolitan region. Table 3 summarizes the average travel time in peak period and sample size for the metropolitan region by mode and by purpose for 1988 and 1994. Results with control and no control for the geographic area are compared.

Home-to-work and work-to-home commutes are longer than trips for other purposes. As shown in Figure 3, the travel time for these two purposes has remained constant over the six year for the drive-alone mode (auto 1). The average time for home-to-work trips stayed at $29.6 \mathrm{~min}$ and for work-to-home trips, it remained at slightly over $33 \mathrm{~min}$. However, for the modes with higher occupancy, the travel time for these two purposes increased. (Examining medians rather than means gives the same basic conclusion).

Figure 3 also compares the commute time with and without control for geographic area. As expected, all the trips using the larger geography took a longer time. For the Twin Cities, as summarized in Table 4 and Figure 3, the average travel time of home-based work trips for drive-alone commuters increased from $22.6 \mathrm{~min}$ in 1990 to $27.2 \mathrm{~min}$ in 2000 . For the other purposes, travel times show the same pattern as the home-based work trips. Furthermore, 
Table 3. Average travel time (in min) for the metropolitan Washington region by mode and by purpose (a.m. and p.m. peak period).

\begin{tabular}{|c|c|c|c|c|c|c|c|c|}
\hline \multirow[t]{2}{*}{ Mode } & \multirow[t]{2}{*}{ Year } & \multicolumn{7}{|l|}{ Purpose } \\
\hline & & $\begin{array}{l}\text { Home to } \\
\text { Work }\end{array}$ & $\begin{array}{l}\text { Work } \\
\text { to } \\
\text { home }\end{array}$ & $\begin{array}{l}\text { Home } \\
\text { to other }\end{array}$ & $\begin{array}{l}\text { Other } \\
\text { to } \\
\text { home }\end{array}$ & $\begin{array}{l}\text { Work } \\
\text { to other }\end{array}$ & $\begin{array}{l}\text { Other } \\
\text { to work }\end{array}$ & $\begin{array}{l}\text { Other } \\
\text { to } \\
\text { Other }\end{array}$ \\
\hline \multirow[t]{3}{*}{ Auto-1 } & 1988 & 29.6 & 33.4 & 17.8 & 21.6 & 26.4 & 23.8 & 17.7 \\
\hline & 1994 (7co) & 29.6 & 33.3 & 16 & 16.5 & 25.9 & 21.4 & 14.3 \\
\hline & 1994 (full) & 30.5 & 35.2 & 17.2 & 17 & 26.8 & 22.2 & 15.5 \\
\hline \multirow[t]{3}{*}{ Auto-2 } & 1988 & 31.6 & 35.7 & 16.8 & 19.3 & 23.6 & 29.5 & 16.6 \\
\hline & 1994 (7co) & 33.8 & 40.4 & 17.1 & 16.7 & 31.7 & 25.3 & 16.8 \\
\hline & 1994 (full) & 33.7 & 42.5 & 17.3 & 16.9 & 30.4 & 24.7 & 17 \\
\hline \multirow[t]{3}{*}{ Auto-3 } & 1988 & 37.8 & 43.1 & 18.8 & 19.2 & 29.8 & 28.9 & 18.6 \\
\hline & $1994(7 \mathrm{co})$ & 41.7 & 45.7 & 20.1 & 17.3 & 42.7 & 36.5 & 16.5 \\
\hline & 1994 (full) & 41.8 & 48.6 & 19.2 & 17.9 & 41.3 & 39.2 & 17.6 \\
\hline \multirow[t]{3}{*}{ Transit } & 1988 & 43.2 & 49.6 & 35.8 & 37.5 & 38.4 & 31.5 & 34.7 \\
\hline & 1994 (7co) & 47 & 54.5 & 57.8 & 44 & 47.1 & 43.7 & 55.4 \\
\hline & 1994 (full) & 47.4 & 55.3 & 58.5 & 44 & 48.5 & 46.1 & 55.6 \\
\hline
\end{tabular}

Note: Bold Italics indicates 1988 baseline, or cells not statistically different from 1988 using a twotailed $t$-test at $95 \%$ confidence level (indicates $t<1.96$ ). Normal font indicates cells are statistically different.

travel times increase by about the same amount using either the same geographic area for 2000 or the larger geographic area.

We compare intra-county work trips to try to control for origin and destination location. This is shown in Figure 4. Perhaps, work trips are taking longer due to people traveling farther. This seems not to be the case in the Twin Cities. Greater shares of trips were intra-county in 2000 than 1990. Moreover, every intra-county pair had higher travel times in 2000 than 1990. While it is possible to make a longer trip while remaining within the same county, we suspect the dominant factor is rising congestion - travel speeds dropping faster than people can relocate to manage their commutes. It is also possible people are indifferent to small changes in commute times below a threshold (tolerance theory) (say the $30 \mathrm{~min}$ or so Washington DC has), and so strong preferences have yet to kick in.

\section{Summary and conclusions}

It was previously observed in metropolitan Washington DC, over the same geographic area, the average commuting times remain stable between 1968 and 


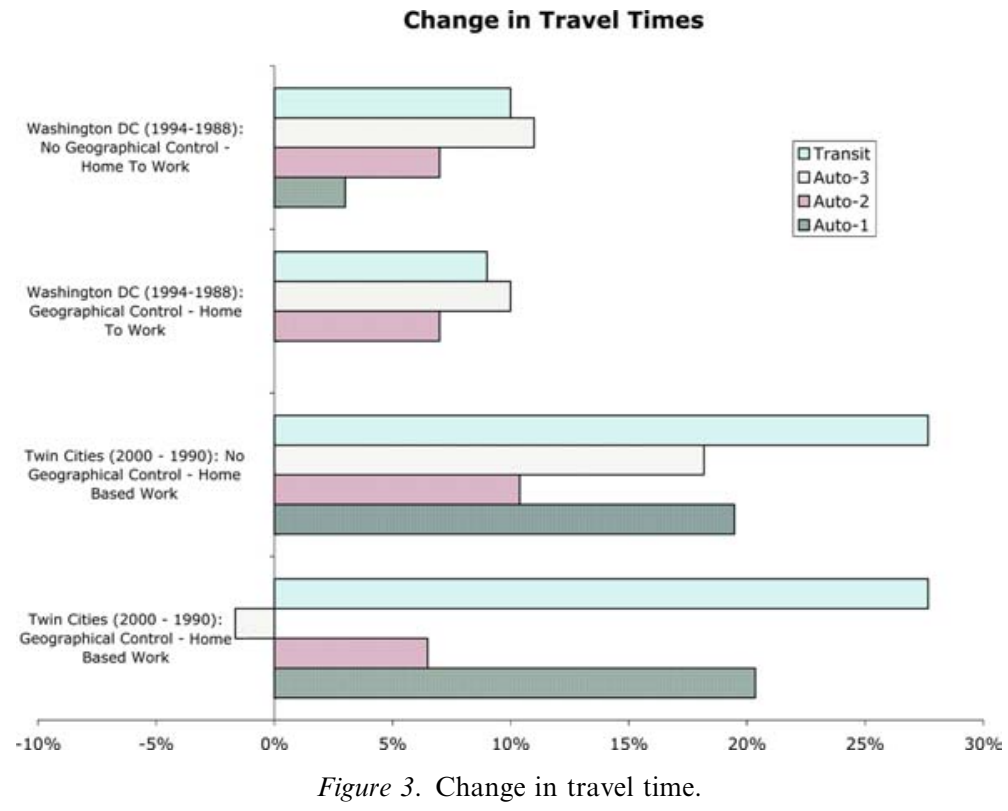

Table 4. Average travel time (in min) for the metropolitan Twin Cities region by mode and by purpose (a.m. and p.m. peak period).

\begin{tabular}{llll}
\hline Mode & Year & Work & Other (Home-based) \\
\hline Auto-1 & 1990 & 22.6 & 14.8 \\
& $2000(7 \mathrm{co})$ & 27.2 & 17.6 \\
& 2000 (full) & 27.0 & 17.8 \\
Auto-2 & 1990 & 23.1 & 14.7 \\
& $2000(7 \mathrm{co})$ & 24.6 & 16.4 \\
& 2000 (full) & 25.5 & 16.4 \\
Auto-3 & 1990 & 24.2 & 14.9 \\
& $2000(7 \mathrm{co})$ & 23.8 & 15.7 \\
& 2000 (full) & 28.6 & 16.5 \\
Bus & 1990 & 32.9 & 29.2 \\
& $2000(7 \mathrm{co})$ & 42.0 & 33.7 \\
& 2000 (full) & 42.0 & 33.2 \\
\hline
\end{tabular}

Note: Bold Italics indicates 1990 baseline, or cells not statistically different from 1990 using a twotailed $t$-test at $95 \%$ confidence level (indicates $t<1.96$ ).

1988 despite the increase in commuting distance and congestion. (And the numbers are the same as found in Whyte (1957).) Fixing the area for 1994 to be consistent with the area from 1988 shows commuting times that are statistically equal (though higher) (and for drive-alone commuters, identical). Nevertheless, considering the new larger metropolitan area, the commuting times in 1994 


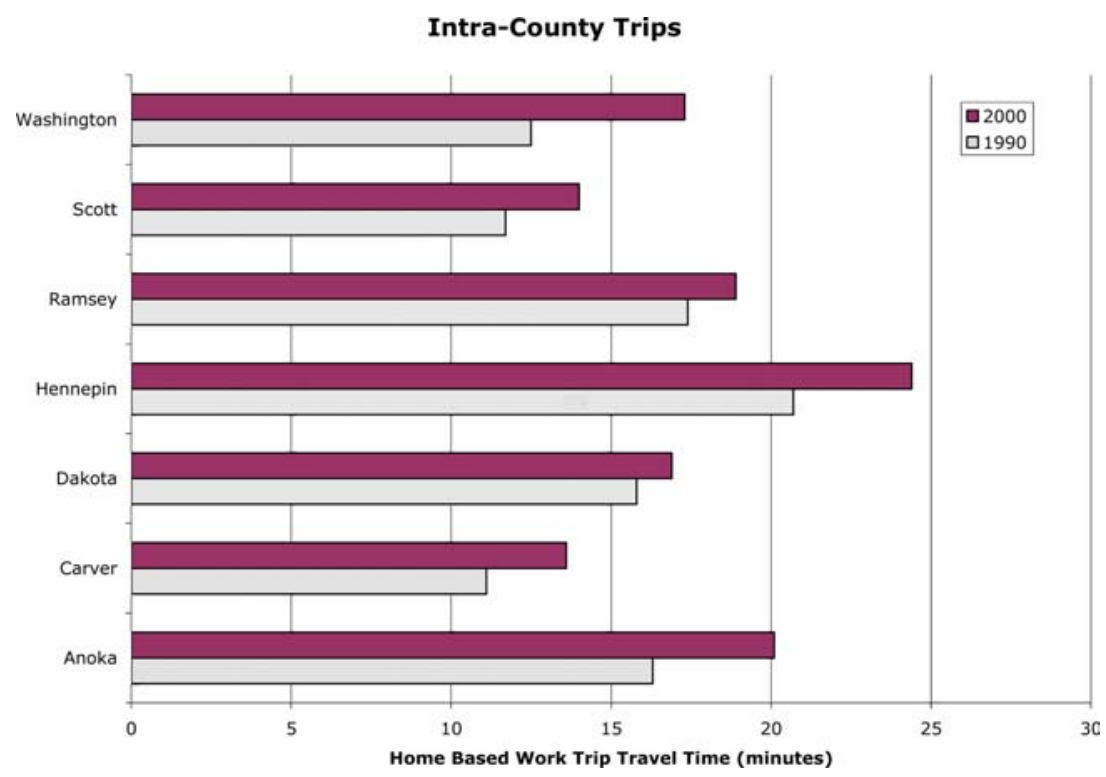

Figure 4. Twin Cities intra-county drive-alone home-based work trip travel time (min).

show a $10 \%$ increase over 1988. Overall, time spent traveling rose as well (by $5 \mathrm{~min}$ in the same area, $7 \mathrm{~min}$ in the larger area), thus continuing a trend from 1968 (time spent traveling between 1968 and 1988 increased from 72-95 min).

In the Twin Cities, commuting times (and total travel times) rose between 1990 and 2000, but remain lower than the times in Washington DC. Similarly, U.S. Census data for most metropolitan areas show higher times in 2000 than 1990, but most metropolitan areas either remained the same physical size or increased, raising the question of whether these rises are statistical artifacts due to changing geography. However, we would expect that a smaller metropolitan area is more likely to see an increase in travel times than a larger one, and Washington remains larger than the Twin Cities.

What do these results imply for metropolitan transportation planning? One could suppose that there is a travel time tolerance. So long as commuters are well under the tolerance, they will not necessarily make decisions to maintain or reduce commuting duration. But when the tolerance is reached, unwillingness to travel more may dominate other considerations. However, to call this a budget may overstate the case; some people will make long trips while opportunities are there, and others will not; it is simply a matter of individual preferences. People will be willing to travel farther in areas with more opportunities (large cities), but as cities grow in size, the amount of extended travel exhibits diminishing marginal returns. Imposing a simple budget on metropolitan models is wrong, although incorporating real, congested travel 
times in travel demand (trip distribution, mode choice) modeling (ensuring an equilibrium between supply and demand) still seems warranted.

These findings do raise interesting questions concerning geographical analyses of this type. Clearly expanding the region increases commuting times, as exurbanites (who have fewer nearby job opportunities) have longer commutes than those who live closer in (who have many nearby opportunities). There may be some off-setting effects, commuter rail or Metro in the DC region and HOV in both regions increase the speed for some commuters in specific corridors, but cannot fully compensate for the increasing distance traveled. To the extent that the recent rise in commuting times is associated with simply increasing the area considered "metropolitan", it is a statistical artifact. But when times increase within the same geographical boundaries because of congestion, or a willingness to spend a greater time traveling to achieve other objectives (e.g. a larger house), we have a more severe problem. As most metropolitan areas are growing faster in space than in population, that may indicate an increasing willingness to trade-off time for space, or an inability to rationally relocate to compensate for rapidly rising congestion.

\section{References}

Barnes G \& Davis G (1999) Understanding Urban Travel Demand: Problems, Solutions, and the Role of Forecasting. Report \#2 in the Series: Transportation and Regional Growth Study CTS 99-02, Center for Transportation Studies, University of Minnesota.

Barr CL (2000) Testing for the Significance of Induced Highway Travel Demand in Metropolitan Areas. Transportation Research Board 79th Annual Meeting Preprint CD-ROM, Transportation Research Board, National Research Council, Washington DC, January 2000.

Becker G (1965) A theory of the allocation of time. The Economic Journal 75: 493-517.

Clark WAV \& Burt J (1980) The impact of workplace on residential relocation. Annals of the Association of American Geographers 79: 59-67.

Clark WAV, Huang Y \& Withers S (2003) Does commuting distance matter? Commuting tolerance and residential change. Regional Science and Urban Economics 33: 199-221.

Clark WAV \& Kuijpers-Linde M, (1994) Commuting in restructuring urban regions. Urban Studies 31: $465-483$.

Clark WAV \& Withers SD, (1999) Changing jobs and changing houses: Mobility outcomes of employment transitions. The Journal of Regional Science 39: 653-673.

Douglas GB (1997) Urban Design, Urban Form, and Employee Travel Behavior. Sixth Transportation Research Board Conference on the Application of Transportation Planning Methods 1997.

Dowling RG \& Colman SB (1995) Effects of increased highway capacity: Results of household travel behavior survey. Transportation Research Record 1493: 143-149.

Dowling RG \& Colman, S.B. (1998) Effects of Increased Highway Capacity: results of a Household Travel Behavior Survey. Transportation Research Circular, no. 481: Highway Capacity Expansion and Induced Travel-Evidence and Implications, (pp. 21-32), Transportation Research Board, National Research Council, Washington DC, February 1998. 
Dunne JP (1984) Elasticity measures and disaggregate choice models. Journal of Transport Economics and Policy 18(2): 189-197.

Fulton LM, Meszler DJ, Noland RB \& Thomas JV (2000) Statistical Analysis of Induced Travel Effects in the U.S. Mid-Atlantic Region. Transportation Research Board 79th Annual Meeting Preprint CD-ROM, Transportation Research Board, National Research Council, Washington DC, January 2000.

Getis A, (1969) Residential location and the journey to work. Proceedings of the Association of American Geographers 20(1): 55-59.

Giuliano G (1995) The Weakening Transportation-Land Use Connection. Access. Spring: 3-11

Giuliano G \& Small KA (1993) Is the journey-to-work explained by urban structure? Urban Studies 30(9): 1485-1500.

Goodwin PB (1996) Empirical evidence on induced traffic. Transportation 23: 23-54.

Hansen M \& Huang Y (1997) Road supply and traffic in California urban areas. Transportation Research: Part A, Policy and Practice 31A(3): 205-218.

Hupkes G (1982) The law of constant travel time and trip-rates. Futures 38-46.

Jones P (1990) Developments in dynamic and activity-based approaches to travel analysis, Oxford Studies in Transport.

Kain JF \& Fauth GR (1977) The effects of urban structure on automobile ownership and journeyto-work mode choices. Transportation Research Record 658: 9-17.

Kölbl R. \& Helbing D (2003) Energy laws in human travel behaviour New Journal of Physics 5: $48.1-48.12$.

Kraan M (1997) In search for limits to mobility growth with a model for the allocation of time and money. Activity-based Approaches to Travel Analysis: 89-115.

Levinson HS (1963) Effects of Density on Urban Transportation Requirements. Highway Research Record, Highway Research Board, 1963.

Levinson DM, (1997) Job and housing tenure and the journey to work. The Annals of Regional Science 31: 451-471.

Levinson DM (1998) Accessibility and the journey-to-work. Journal of Transport Geography 6(1): $11-21$.

Levinson D \& Kanchi S (2002) Road capacity and the allocation of time. Journal of Transportation and Statistics 5(1): 25-46.

Levinson D \& Kumar A (1994) The rational locator: Why travel times have remained stable. Journal of the American Planning Association 60(3): 319-332.

Levinson D \& Kumar A (1995) Activity, travel, and the allocation of time. Journal of the American Planning Association 61(4): 458-469.

Loudon WR (1997) Census Journey-to-Work Long-form Survey: Does it support state and Metropolitan Transportation Planning? Transportation Research Board Conference Proceedings 13 , vol. 1

Luk JYK \& Chung E (1997) Induced Demand And Road Investment: An Initial Appraisal. Vermont South, Victoria: Australian Road Research Board.

Mackie PJ, Jara-diaz S \& Fowkes AS (2001) The value of travel time savings in evaluation. Transportation Research part E, 37.

Marchetti C (1994) Anthropological invariants in travel behavior. Technological Forecasting and Social Change 47: 75-88.

Marshall NL (2000) Evidence of Induced Demand in the Texas Transportation Institute's Urban Roadway Congestion Study Data Set. Transportation Research Board 79th Annual Meeting Preprint CD-ROM, Transportation Research Board, National Research Council, Washington DC, January 2000.

McCarthy PS (1997) The role of captivity in aggregate share models of intercity passenger travel. Journal of Transport Economics and Policy 31(3): 293-308. 
Metropolitan Council, Minnesota Department of Transportation Regional Transit Board, Transportation Advisory Board (1997) Twin Cities metropolitan area travel behavior inventory, 1990 home interview survey methodology and results.

Metropolitan Washington Council of Governments (1997) 1994 COG/TPB household travel study for the metropolitan Washington region, technical report and documentation.

Milone RJ (1993) An Analysis of Income Stratified Work Trip Distributions for Washington DC. Fourth National Conference on Transportation Planning Methods Applications Compendium.

Mokhtarian P \& Chen C (2003) TTB or Not TTB, that is the Question: A Review and Analysis of the Empirical Literature on Travel Time (and Money) Budgets. Presented at 2003 Transportation Research Board Conference, Washington DC.

Noland RB (1999) Relationships Between Highway Capacity and Induced Vehicle Travel. Transportation Research Board 78th Annual Meeting Preprint CD-ROM, Transportation Research Board, National Research Council, Washington DC, January 1999.

Noland RB \& Cowart WA (2000) Analysis of Metropolitan Highway Capacity and the Growth in Vehicle Miles of Travel. Transportation Research Board 79th Annual Meeting Preprint CDROM. Transportation Research Board, National Research Council, Washington DC, January 2000.

NuStats Partners (2001) Twin Cities metropolitan area travel behavior inventory, 2001 home interview survey technical report.

Pisarski A (2002) Testimony For "Mobility, Congestion and Intermodalism" before the United States Senate Committee on Environment and Public Works March 19, 2002 Washington DC http://www.senate.gov/ epw/Pisarski_031902.htm.

Prendergast LS \& Williams RD (1981) Individual travel time budgets. Transportation Research 15A(1): $39-46$.

Purvis C (1995) Changes in regional travel characteristics and travel time expenditures in the San Francisco Bay Area: 1960-1990. Transportation Research Record 1466: 99-110.

Redmond LS \& Mokhtarian PL (1999) The positive utility of the commute: Modeling ideal commute time and relative desired commute amount. Transportation

Rossi E (1997) Speed in Transport. Report EURES, Freiburg.

Rouwendal J \& Rietveld P (1994) Changes in commuting distances of Dutch households. Urban Studies 31: 1545-1557.

Rouwendal J (1999) Spatial job search and commuting distances. Regional Science and Urban Economics 29: 491-517.

Shafer A (2000) Regularities in travel demand: An international perspective Journal of Transportation and Statistics 3(3): 1-31.

Shunk GA (1995) Uses of census data for travel research. Transportation Research Board Conference Proceedings 4: 68-74.

Tanner JC (1981) Expenditure of time and money on travel. Transportation Research 15A(1): $25-38$.

Texas Transportation Institute (2001) The 2001 Urban Mobility Report. The Texas A \& M University System. http://mobility.tamu.edu.

United States Census Bureau (2002) 2000 Census Statistics http://www.census.gov.

van Ommeren J (1998) On the job search behavior: The importance of commuting time. Land Economics 74: 526-540.

van Ommeren JN (1999) Job moving, residential moving and commuting: A search perspective. Journal of Urban Economics 46: 230-253.

van Ommeren JN, Rietveld P \& Nijkamp P (1996) Residence and workplace relocation: A bivariate duration model approach. Geographical Analysis 38: 315-329.

van Ommeren JN, Rietveld P \& Nijkamp P (1997) Commuting in search of jobs and residences. Journal of Urban Economics 42: 402-421. 
van Ommeren JN, Rietveld P \& Nijkamp P (1998) Spatial moving behavior of two earner households. Journal of Regional Science 38: 23-41.

Vivier J (2001) Mobility and accessibility - complementary or contradictory objectives? Public Transport International 50(5): 4-11.

Wee B van, Rietveld P \& Meurs H (2002) A constant travel time budget? In search for explanations for an increase in average travel time. Research Memorandum 2002-31 Free University of Amsterdam.

Whyte WH Jr (ed.) (1957) The Exploding Metropolis. Berkeley, CA: University of California Press.

Zahavi Y (1974) Travel Time Budget and Mobility in Urban Areas, Federal Highway Administration. Washington DC, U.S. Department of Transportation, May 1974, NTIS PB 234145.

Zahavi Y \& Ryan J (1980) Stability of travel components over time. Transportation Resarch Record 750: 19-26.

Zahavi Y \& Talvittie A (1980) Regularities in travel time and money expenditures. Transportation Research Record 750: 13-19.

\section{About the authors}

David Levinson is an Assistant Professor in the Department of Civil Engineering at the University of Minnesota, where he has recently completed Assessing the Benefits and Costs of ITS, co-edited with David Gillen and The Transportation Experience, written with Bill Garrison. His current research focuses on understanding the process of network growth, evaluating transportation technology and policy, and modeling travel behavior.

Yao Wu, a transportation engineer with Fehr \& Peers, is a recent graduate of the University of Minnesota receiving his Master's Degree in Civil Engineering. His focus of graduate study is transportation demand modeling and he is currently working on traffic impact studies and transportation operational analyses. 